ROCZNIKI HUMANISTYCZNE

Tom LXVIII, zeszyt $10 \quad-\quad 2020$

DOI: http://dx.doi.org/10.18290/rh206810-12

ADAM WARCHOŁ

\title{
TEACHING ENGLISH PRONUNCIATION TO ESP LEARNERS: BASIC VIEWS AND RECOMMENDATIONS
}

\section{INTRODUCTION}

English has achieved "a genuinely global status" since it developed a special role worldwide, recognized either as an official language of a country or as "a priority in a country's foreign-language teaching" (Crystal, A Dictionary 3-4). For so many learners, the key objective of learning English is not only gaining access to educational perspectives, but also to achieve technical, professional, social and personal goals. In that case, integrated instruction has to address a range of L2 skills simultaneously. For instance, teaching reading can be easily tied to writing and vocabulary instruction, and oral skills to teaching pronunciation, listening, and cross-cultural pragmatics (Hinkel). Since sounds play a significant role in communication, foreign language teachers should attribute proper importance to teaching pronunciation in their classes.

With this in mind, the purpose of the current paper is to present the basic views and recommendations of some teaching techniques in pronunciation instruction of adult ESP learners. ESP trainings are meant here as language courses tailored to satisfy very specific needs clearly articulated by adult students. In general, there are distinguished three main types of such ESP courses, e.g. English for science and technology, English for business and economies and English for social sciences. Each of these can be subdivided into English for occupational or academic purposes, for medical, technology, law studies, etc. (Hutchinson and Waters 17; Basturkmen 16).

AdAm Warchol, MA - PhD student at the Maria-Curie Sklodowska University (UMCS); holds classes for UMCS students (A VISTA translations) and is a specialist English teacher; e-mail: warcholadam82@gmail.com. ORCID: https://orcid.org/0000-0003-2304-9125.

Mgr ADAM WARCHOE - doktorant na Uniwersytecie Marii Curie-Skłodowskiej; prowadzi zajęcia dla studentów UMCS (tłumaczenia A VISTA) oraz jest lektorem specjalistycznego języka angielskiego; e-mail: warcholadam82@gmail.com. ORCID: https://orcid.org/0000-0003-2304-9125. 
The article comprises four sections. Opened with a short introductory part and having the aim of the paper specified, the article deals in section 2 with defining pronunciation and emphasizing its significance as a key factor to obtain full communicative competence. The goal of section 3 is to discuss the basic strategies for teaching pronunciation that can help adult ESP learners meet their personal and professional requirements. The paper closes with concluding remarks and a proven confirmation that, with careful preparation and integration, pronunciation can play a substantial role in supporting the learners' complete communicative set of skills.

\section{THE MEANING OF PRONUNCIATION}

The study of pronunciation consists of phonetics, understood as an attempt to describe the physical sounds of language, and phonology, which tries to understand how sounds are perceived and categorized in a particular language to create meaning. As defined by Kelly and Gilakjani ("A Study of factors" and "English Pronunciation"), pronunciation is the production of sounds that are used to make meaning. It comprises the attention to the particular sounds of a language (segments), aspects of speech beyond the level of the individual sound, such as intonation, phrasing, stress, timing, rhythm (suprasegmental aspects), how the voice is projected (voice quality) and attention to gestures and expressions. Hence, pronunciation includes both segmental and suprasegmental features, which are all combined during the process of speaking, and are therefore usually best assimilated as an integral part of the spoken language.

Explicit pronunciation instruction has been largely unnoticed during the past 30 years, which resulted from to the perceived insignificance of pronunciation in effective communication (Elliot; Hismanoglu). Recent decades have witnessed an ongoing debate over the implications of pronunciation teaching due to the internationalization of English. Some approaches to teaching, e.g. the Reformed Method and Audiolingualism, raised pronunciation to a highpoint of importance, while other methods, e.g. the Cognitive Movement and early Communicative Language Teaching, mostly disregarded pronunciation (Celce-Murcia, Brinton and Goodwin). ${ }^{1}$ Pronunciation research

\footnotetext{
${ }^{1}$ In the course of time, the question of whether explicit pronunciation instruction helps L2 learners to achieve target pronunciation skills has been posed in a number of studies, and such studies reveal a significant relationship between formal instruction and L2 learners' pronuncia-
} 
and pedagogy have long been under the impact of two contradictory principles, the nativeness principle and the intelligibility principle (Levis; Field). The nativeness principle implies the achievement of native-like pronunciation in a foreign language. However, the effect of this principle was rapidly weakened, leading to the logical assumption that aiming at nativeness was an unrealistic goal for both teachers and learners. As referred by Levis, prestige native speaker versions of English are still considered as the proper models for pronunciation learning, though most native speakers of English speak neither General American nor Received Pronunciation (also called BBC English, or simply British English, BrE). Apart from these two commonly-acknowledged accent choices, there is the third opportunity, the Lingua Franca Core (LFC), applied for the millions of non-native English learners. The LFC differs from current pronunciation methodology by emphasizing segmentals (consonants and vowels), moderating the importance of suprasegmentals (rhythm, word stress, and intonation), and reducing the drive for sound correctness, as long as phonological distinctiveness and consistency are maintained (e.g., go may be realized as /gəo/, /gov/, or /go/) (Dauer).

The second principle, i.e. the intelligibility principle, introduced by Levis, indicates that communication can be noticeably successful when foreign accents are remarkable, and that certain sorts of pronunciation errors may have a disproportionate role in weakening comprehensibility. Instead, pronunciation instruction should focus on the features that support understanding, discrediting those that are relatively unhelpful. In other words, there is a need for mastering 'good pronunciation', rather than a perfect accent.

In this light, the first dilemma any pronunciation teacher needs to face up to is what accent and principle should be chosen to teach. According to Morley and Gilakjani ("A Study of factors" and "English Pronunciation"), the reasonable aim of pronunciation teaching should generally be intelligibility since it is a crucial ingredient of communication competence. Yet, despite the recent domination of intelligibility seems to be the objective of pronunciation teaching, both the nativeness and intelligibility principles continue to affect pronunciation in the language curriculum, stressing the importance of a communicative context. Indeed, while native-like pronunciation may be a goal for particular learners (e.g. teachers and those who want to work as air traffic controllers or telephone operators), and while learners should never

tion improvement (Munro and Derwing; Elliot; Fraser). Also, they point at poor knowledge and motivation as a result of ineffective pronunciation agenda not offering an in-depth understanding of such interlingual phonological issues. 
be actively discouraged from setting 'high' goals for themselves, for the majority of adult ESP learners a far more realistic goal is to be comfortably intelligible (Kenworthy; Levis).

\section{BASIC RECOMMENDATIONS \\ FOR PRONUNCIATION INSTRUCTION \\ OF ADULT ESP LEARNERS}

With the emphasis on the importance of meaningful communication and intelligible pronunciation, it is not enough to relegate pronunciation training to separate classes only or even to listening/speaking classes in some programs (Kenworthy; Hismanoglu, ). Instead, as noticed by Chun, the effective approach to teaching pronunciation should be generally based on three principled criteria: (a) pronunciation and intonation are taught in context and in conjunction with speaking skills; (b) pronunciation instruction serves broader communicative purposes; and (c) the teaching of pronunciation and intonation is based on realistic rather than idealistic language prototypes.

\subsection{Adult ESP learners as the target group OF PRONUNCIATION INSTRUCTION}

The approach to English language instruction which adult pronunciation learners may benefit from most is known as English for specific purposes, ESP (also called LSP), or a method that is needs-based, pragmatic, efficient, cost-effective, and functional (Belcher). Significantly, ESP focuses more on language in context than on teaching grammar and language structures. It combines subject-matter and English language instruction; hence, students learn vocabulary and structures in a meaningful context that pertains to their real or future jobs. Subject-matter knowledge raises their motivation and gives them the framework they need to understand the classroom English (Sobkowiak).

As remarked by Anna Turula, adult learners, being already past the critical age, are less efficient in learning (phonology, accent, syntax, etc.); and they may enter the classroom with negative self-attitudes and anxiety, based on the fact that they are older. On the other hand, adults are also well defined to bring into the classroom motivation, ability to take charge of their own lives, experience, and cognitive maturity. As an extra advantage, their 
intellectual maturity facilitates a proper valuation of the practicability of classroom activities. At the same time, what a lot of adult learners find challenging is lack of time, costs of education, and lack of their autonomy and experience, due to their earlier schooling, inappropriate previous educational experience or personal immature characteristics (Cercone; Turula).

\subsection{TeChNiQues of teaching PRONUNCIATION to ESP LEARNERS}

Adult ESP learners mostly desire to communicate not only with native English-speakers, but also with non-native speakers as it is the Lingua Franca of today with many universities and careers offering opportunities in English. Hence, the first task of teachers, course designers and syllabus writers is to conduct a needs analysis, giving insight into the variety of language to be taught and the approach to be taken to provide students with the knowledge and skills they require most (Hutchinson and Waters 17; Basturkmcn 16). With a big variety of pronunciation activities available nowadays, the fundamental principle for pronunciation instructor is to help students acquire knowledge and improve their communication skills that will contribute to increased intelligibility and comprehensibility (Dauer).

Furthermore, Winiewska points out that a code with phonetic symbols is one of the techniques all teachers employ at the very beginning of their pronunciation instruction. Since each symbol describing a single sound is different from a letter of the alphabet, it takes time to learn the code and apply it. Undoubtedly, one obvious benefit from learning the code is the ability to check the pronunciation of unfamiliar words in a dictionary by students themselves.

Undeniably, segmental features that relate to sounds within words at the micro level (for example, $l$ as in little, $r$ as in ring, $\alpha$ as in cat, minimal pairs such as ship/sheep) are important (Kelly). Nonetheless, successful communicative pronunciation competence can be achieved through improving suprasegmental production more than segmentals. As confirmed by Gilakjani ("A Study of factors"), suprasegmental features relate to sounds at the macro level, while linking, intonation and stress are the best known features for effective pronunciation at this level. Indeed, word stress, intonation, and rhythm as the prosodic features of language are extremely important for comprehensibility (O'Brien). Therefore, to practise these features, teachers should use listening activities, e.g. tasks to listen to rising intonation in Yes/ No questions, to compare question intonation in English with that of their 
native languages, to imitate dialogues on duration of stress, perform plays, or watch videos).

Besides, a set of exercises and drill-types should be a part of a teaching inventory. There are several methodological principles which the teacher should be attentive to, and which may assist him/her in the course of teaching. All the examples of communication, both free (in the form of directions, comments, conversation with students) and directed (in the form of exercises, dialogues, dictation, and pronunciation instruction per se), provide students with a model that they should benefit from. Accordingly, students try to follow the example of the teacher's utterance, his/her way of pronouncing consonants and vowels, rhythm, speed, intonation, stress, etc. An articulatory setting (AS) is the basic or underlying configuration of a speaker's vocal apparatus that facilitates pronouncing a given language (Messum "What if children" and "Understanding"). The teacher must continually remind students of the repeated attempts until they perform satisfactorily. In other words, sometimes the teacher is constrained to emphasize the segmentals if students need it.

The list below ${ }^{2}$ presents a summary of classroom techniques and approaches that have been used for pronunciation instruction, and are highly recommended to apply for ESP learners:

- Subject-matter specialist sources applied for the syllabus in accordance with the target group of learners who are trained to certain professions.

- Fluency-building activities: effective listening exercise, fluency workshop, discussion wheel, value topics and personal introduction collage.

- Visual and auditory reinforcement: charts, minimal pairs, diagrams and sketches on the board or the overhead projector through the use of flashcards and wall charts.

- Tactile reinforcement: having students place their fingers on their throat or cup their hands over their ears to experience the vibration on the vocal cords.

- Kinaesthetic reinforcement: the use of hand signals and body movement to augment other instructional practices.

- The use of authentic materials: such as anecdotes, jokes, advertising copy, comic strips, passages from literature and so on.

- The use of textbooks which provide the most accessible and permanent indication of the content and methods of phonetics teaching (e.g., Ship or Sheep? Introducing English pronunciation, by Baker; Teaching Pro-

\footnotetext{
${ }^{2}$ The list is prepared based on the author's personal teaching experience of ESP learners, yet inspired by Celce-Murcia et al. (290-318).
} 
nunciation: A Reference for Teachers of English to Speakers of Other Languages, by Celce-Murcia et al.; Pronunciation Practice Activities, by Hewings; Teaching English Pronunciation, by Kenworthy; Tips for Teaching Pronunciation: A Practical Approach, by Lane; English Phonology and Pronunciation Teaching, by Rogerson-Revell; How to Teach Pronunciation, by Kelly; A Dictionary of Linguistics and Phonetics by Crystal, A Dictionary; and other specialized books reliant on ESP learners' goals).

- Multimedia enhancement: the use of video recorders, computer displays and the use of software. By means of audio CDs and DVDs, teachers can give learners meaningful exposure to variation in pronunciation and increase their communicative competence.

- Techniques from psychology: the use of breathing exercises in which students stand and place their hands on their diaphragms, breathing deeply in and out which can be accompanied by guided imagery activities, visualization activities in which teachers get students to call up images.

- Techniques from theatre arts: the employment of drama coaches to give students better control over their articulation, pitch, volume and rate of speech, e.g. role-plays of requests that learners have to make (e.g., to ask a boss for a day off).

- Continuous evaluation through careful observations of communication failures and common mispronounced words performed by learners within a classroom during presentations, summarizing the student's strengths and weaknesses, loud reading or pair/group work. The checklist of observations can also be used to make learners conscious of particular features of speech that have the potential to cause difficulties for intelligibility and to help them develop their own pronunciation objectives.

In short, the above-mentioned range of activities targets pronunciation skills and is worth implementing for ESP instruction. The choice of techniques and manners of instruction depends on learner- and context-related variables (Munro and Derwing). Indeed, as Ashby and Przedlacka elucidate, any instruction is supposed to take into consideration the background in which teaching is accomplished, the curricula followed, the methods, materials and assessments employed, and the verification of standards attested.

Nonetheless, the major problem that L2 learners may encounter with pronunciation instruction is related to their need to alter a conceptual pattern suitable for their L1 that they have internalized in childhood. That is why, adult L2 learners need some guide in categorizing or conceptualizing sounds 
in a way suitable to English. Simply observing a speech-wave or a diagram of the articulation of a sound will not help learners if they are not supported to comprehend what features of the sound are prominent and provided with appropriate ways of thinking about the sound so that they can rearticulate it.

\section{CONCLUDING REMARKS}

The present paper intended to reflect upon the covering aspects of pronunciation instruction, with a description of adult ESP learners. The importance of pronunciation as a strategic factor to obtain full communicative competence was stressed.

To conclude, today's English pronunciation pedagogy has the objective of helping learners achieve general intelligibility, not radical accent adjustment. Indeed, pronunciation should be viewed as more than correct production of phonemes: it must be regarded in the same light as grammar, syntax, and discourse that are all an important part of communication. Fraser recaps that pronunciation includes all those aspects of speech which allow an easily intelligible flow of speech, including segmental articulation, rhythm, intonation and phrasing, and more peripherally even gesture, body language and eye contact. Overall, successful pronunciation instruction depends on whether first both the teachers and learners have set individual teaching and learning goals. Pronunciation should be taught at all levels and contextualized exercises and drills should fit into communicative approaches (O'Brien). Practice should begin with listening activities that sensitize students to a specific prosodic aspect and should then proceed to explaining the feature in question, including a comparison with L1 if possible. Training should then move to imitation and rehearsed speaking activities in which students read dialogues. Finally, students should be expected to perform spontaneous role plays with partners on similar topics and with the same prosodic emphasis. If necessary, students can be given situations and roles to play, based on their own work and education experience. External stimuli such as films, video and music should be frequently applied as a highly-motivating tool for having the students become more interested in English learning.

Drawing some implications for the future, we can conclude that pronunciation ought to be taught as an integral part of oral language use, as part of the means for creating both referential and interactional meaning, not just as a part of the oral production of words and sentences. Pronunciation creates 
a natural link to other aspects of language use, such as listening, vocabulary, and grammar. In addition, learners should be guided in class to find out their original strategies on English pronunciation. For example, appropriate assignments and feedback by teachers should be continuously offered to learners. With the teacher acting as a 'speech coach', rather than as a mere checker of pronunciation, feedback provided to the student can encourage ESP learners to improve their pronunciation. If these conditions are met, all learners can succeed in learning the pronunciation of a foreign language.

In a nutshell, at any level students need to learn pronunciation to get understood in English. Besides, proper L2 pronunciation makes a learner more confident, reducing the fear of negative evaluation that is linked to anxiety and results in a speaker's weaker intelligibility (Szyszka 2).

\section{BIBLIOGRAPHY}

Ashby, Michael G., and Joanna Przedlacka. Towards a History of Teaching, Learning and Assessment in Phonetics. University College London, 2013.

Baker, Ann. Ship Or Sheep? Introducing English pronunciation. Cambridge UP, 1981.

Basturkmen, Helen. Developing Courses in English for Specific Purposes. Palgrave Macmillan, 2010.

Belcher, Diane D. "English for Specific Purposes: Teaching to Perceived Needs and Imagined Futures in Worlds of Work, Study, and Everyday Life." TESOL Quarterly, vol. 40, issue 1, 2006, pp. 133-156.

Celce-Murcia, Marianne, Donna M. Brinton, and Janet M. Goodwin. Teaching Pronunciation: A Reference for Teachers of English to Speakers of Other Languages. Cambridge UP, 1996.

Cercone, Kathleen. "Characteristics of Adult Learners with Implications for Online Learning Design." AACE Journal, vol. 16, no. 2, 2008, pp. 137-159.

Chun, Dorothy. Discourse Intonation in L2. John Benjamins Publishin Company, 2002.

Crystal, David. English as a Global Language. Cambridge UP, 1997. $2^{\text {nd }}$ edition: 2003.

- A Dictionary of Linguistics and Phonetics. Blackwell, 2003.

Dauer, Rebecca. M. "The Lingua Franca Core: A New Model for Pronunciation Instruction?" TESOL Quarterly, vol. 39, no. 3, 2005, pp. 543-550.

Elliot, A. Raymond. "Foreign Language Phonology: Field Independence, Attitude, and the Success of Formal Instruction in Spanish Pronunciation." The Modern Language Journal, vol. 79 , no. 4,1995 , pp. 530-542.

Field, John. "Intelligibility and the Listener: the Role of Lexical Stress." TESOL Quarterly, vol. 39, no. 3, 2005, pp. 399-423.

Fraser, Helen. Teaching Pronunciation: A Handbook for Teachers and Trainers Three Frameworks for an Integrated Approach. Department of Education Training and Youth Affairs (DETYA), 2001. 
Gilakjani, Abbas Pourhossein. "A Study of Factors Affecting EFL Learners' English Pronunciation Learning and the Strategies for Instruction." International Journal of Humanities and Social Science, vol. 2, no. 3, 2012, pp. 119-128.

. "English Pronunciation Instruction: Views and Recommendations." Journal of Language Teaching and Research, vol. 8, no. 6, 2017, pp. 1249-1255.

Hewings, Martin. Pronunciation Practice Activities: A Resource Book for Teaching English Pronunciation. Cambridge UP, 2004.

Hinkel, Eli. "Current Perspectives on Teaching the Four Skills.” TESOL Quarterly, vol. 40, no. 1, 2006, pp. 109-131.

Hismanoglu, Murat, and Sibel Hismanoglu. "A qualitative Report on the Perceived Awareness of Pronunciation Instruction Increasing Needs and Expectations of Prospective EFL Teachers." Asia-Pacific Edu Res, vol. 22, no. 4, 2013, pp. 507-520.

Hutchinson, Tom, and Alan Waters. English for Specific Purposes: A Learning-centred Approach. Cambridge UP, 1991.

Kelly, Gerald. How to Teach Pronunciation. Pearson Education Limited, 2000.

Kenworthy, Joanne. Teaching English Pronunciation. Longman, 1987.

Lane, Linda. Tips for Teaching Pronunciation: A Practical Approach. Pearson Longman, 2010.

Levis, John M. "Changing Contexts and Shifting Paradigms in Pronunciation Teaching." TESOL Quarterly, vol. 39, no. 3, 2005, pp. 369-377.

Messum, Piers. "What if Children Don't Learn to Pronounce by Imitation. How Should we Teach Older Learners?" IATEFL Pronunciation Special Interest Group Newsletter, vol. 39, 2008, pp. 16-21.

"Understanding and Teaching the English Articulatory Setting." Speak Out! IATEFL Pronunciation Special Interest Group Newsletter, vol. 43, 2010, pp. 20-29.

Morley, Joan. "The Pronunciation Component in Teaching English to Speakers of Other Languages.” TESOL Quarterly, vol. 25, no. 3, 1991, pp. 481-520.

Munro, Murray J., and Tracey M. Derwing. "Foreign accent, Comprehensibility, and Intelligibility in the Speech of Second Language Learners." Language Learning, vol. 49, 1999, pp. 285-310.

O’Brien, Mary G. "Pronunciation matters." Die Unterrichtspraxis [Teaching German], vol. 37, no. 1, 2004, pp. 1-9.

Rogerson-Revell, Pamela. English Phonology and Pronunciation Teaching. Continuum, 2011.

Sobkowiak, Włodzimierz. "Pronunciation in EFL CALL." Teaching English with Technology, vol. 5 , no. 1,2005 , pp. 1-7.

Szyszka, Magdalena. Pronunciation Learning Strategies and Language Anxiety: In Search of an Interplay. Springer International Publishing, 2017.

Turula, Anna. Teaching English as a Foreign Language: From Theory to Practice ... and All the Way Back. Wyższa Szkoła Lingwistyczna, 2010.

Winiewska, Hanna. "Methods and Techniques in Pronunciation Teaching." Publikacje edukacyjne, www.publikacje.edu.pl/pdf/7039.pdf. Accessed 10.05.2016. 


\section{NAUCZANIE WYMOWY \\ SPECJALISTYCZNEGO JĘZYKA ANGIELSKIEGO: PRZEGLĄD METOD I ZALECENIA}

Streszczenie

Celem niniejszego artykułu jest zaprezentowanie różnych poglądów na temat wymowy języka angielskiego przez dorosłych studentów. W artykule podkreślono znaczenie wymowy jako strategicznego czynnika do uzyskania pełnej kompetencji komunikacyjnej oraz przedstawiono kilka podstawowych sugestii na temat nauczania dorosłych odbiorców wymowy języka angielskiego. Podkreślono znaczenie stymulowania motywacji i rozwoju dorosłego studenta oraz wagę kształcenia umiejętności poprawnego wymawiania pojedynczych angielskich samogłosek, spółgłosek, dyftongów, słów, zwrotów oraz całych zdań, z zachowaniem zasad poprawnej intonacji, akcentu, rytmu i technik skracających wypowiedź. Oprócz typowych ćwiczeń językowych z wymowy studenci również pracują na materiale specjalistycznym dostosowanym do potrzeb rynku pracy i komunikacji życia codziennego.

Słowa kluczowe: edukacja; wymowa w języku angielskim; dorośli studenci; cechy segmentalne i suprasegmentalne.

\section{TEACHING ENGLISH PRONUNCIATION TO ESP LEARNERS: BASIC VIEWS AND RECOMMENDATIONSY}

\section{Sum mary}

Pronunciation is an integral part of foreign language learning since it directly affects learners' communicative competence as well as their performance (Celce-Murcia et al.). The aim of this article is to present some views concerning the pronunciation instruction of adult learners who study English for special purposes (ESP learners). Traditionally viewed as the correct production of individual sounds or isolated words, pronunciation should be regarded as a crucial part of communication, combined with classroom activities, and seen in the same light as the other aspects and skills of the English language, such as vocabulary, grammar, reading, writing, and especially listening and speaking. The overall goal for the adult ESP learner is still to develop spoken English that is easily understood, serves the learner's individual needs, and builds a positive image as an intelligible speaker of a foreign language (Sobkowiak).

Key words: education; pronunciation; ESP learners; segmental and suprasegmental features. 